\title{
Javanese Turmeric (Curcuma xanthorrhiza Roxb.): Ethnobotany, Phytochemistry, Biotechnology, and Pharmacological Activities
}

\author{
Endang Rahmat $\mathbb{D}^{1,2}$ Jun Lee $\mathbb{D}^{1,2}$ and Youngmin Kang $\mathbb{D}^{1,2}$ \\ ${ }^{1}$ University of Science \& Technology (UST), KIOM Campus, Korean Convergence Medicine Major, \\ Daejeon 34054, Republic of Korea \\ ${ }^{2}$ Herbal Medicine Resources Research Center, Korea Institute of Oriental Medicine, 111 Geonjae-ro, Naju-si, \\ Jeollanam-do 58245, Republic of Korea \\ Correspondence should be addressed to Youngmin Kang; ymkang@kiom.re.kr
}

Received 12 March 2021; Accepted 3 June 2021; Published 12 June 2021

Academic Editor: Armando Zarrelli

Copyright (c) 2021 Endang Rahmat et al. This is an open access article distributed under the Creative Commons Attribution License, which permits unrestricted use, distribution, and reproduction in any medium, provided the original work is properly cited.

\begin{abstract}
Curcuma xanthorrhiza Roxb., locally famed as Temulawak, has been extensively utilized in Indonesia as medicinal and nutritional plants since immemorial time. The rhizome of this plant is an important ingredient for jamu formulation (Indonesian traditional medicine). C. xanthorrhiza is traditionally used to treat several ailments such as lack of appetite, stomach disorder, liver illness, constipation, bloody diarrhea, dysentery, arthritis, children's fevers, hypotriglyceridaemia, hemorrhoids, vaginal discharge, rheumatism, and skin eruptions. To date, over 40 active compounds, including terpenoids, curcuminoids, and other phenolic compounds, have been isolated and identified from C. xanthorrhiza Roxb. Some pharmacological tests reported that C. xanthorrhiza Roxb. has antioxidant, antimicrobial, anti-inflammatory, anticancer and antitumor, antidiabetic, and skincare and hepatoprotective properties. Efforts for biotechnologically production of C. xanthorrhiza have also been conducted, resulting in some micropropagation protocols of this plant. The current review focuses on the botanical description and distribution, ethnomedicinal uses, production and conservation status, phytochemical properties, and pharmacological activities of C. xanthorrhiza Roxb. to provide accurate and reliable data for future researches and commercialization purposes.
\end{abstract}

\section{Introduction}

Curcuma xanthorrhiza Roxb. (family: Zingiberaceae) is a native Indonesian highly valuable plant locally familiar as "Temulawak" or Java turmeric. It is mainly cultivated in Indonesia and other Southeast Asian countries such as Malaysia, Thailand, Vietnam, and Phillippines [1, 2]. Recorded in 2019, C. xanthorrhiza was cultivated in Indonesia on a massive scale with a demolished harvested area of more than $13,042,873 \mathrm{~m}^{2}$ producing yields of $29,637,119 \mathrm{~kg}$ [3].

Traditionally, C. xanthorrhiza have been greatly harnessed all over its local distribution area as an ingredient of jamu (Indonesian herbal supplement and medicine) or to medicate and control numerous of sickness and disorders since ancient time including lack of appetite, stomach illness, liver ailments, constipation, bloody diarrhea, dysentery, arthritis, children's fevers, hypotriglyceridemic, hemorrhoids, vaginal discharge, rheumatism, and skin eruptions [4-9]. The efficacy of C. xanthorrhiza for treating various diseases has been confirmed due to having pharmacology properties such as anti-inflammatory, antibacterial, antioxidative, neuroprotective, nephroprotective, antitumor, and hepatoprotective activities [10-18]. C. xanthorrhiza (Temulawak) has also been exported and utilized in Europe at least since 1963, particularly for the treatment of dyspepsia, infections, and skin and liver illness.

Scientific studies showed that the most abundant essential phytochemicals obtained from the C. xanthorrhiza rhizome were terpenoids and curcuminoids [19-21]. Therefore, the medicinal activity of C. xanthorrhiza is mostly caused by these two major groups of compounds [22]. The 
main medicinal part of $C$. xanthorrhiza which contains many sesquiterpenoids and curcuminoids is rhizome [19]. Hence, market demand for rhizome of C. xanthorrhiza is increasing from time to time.

To answer the challenge of increasing global market demand for C. xanthorrhiza, several biotechnology studies through in vitro propagation and production have been carried out. Biotechnological treatments such as elicitation with yeast extract and the addition of colchicine have been carried out to enhance the growth of biomass and accumulation of active compound content of C. xanthorrhiza $[23,24]$. Even so, biotechnology research for this plant is still very limited, and further comprehensive research is needed.

However, although there are many reports that explain the identification of secondary metabolites and pharmacological activities of $C$. xanthorrhiza, there is no comprehensive review published for critically summarizing these studies and offering potential future applications for both research and treatment. Therefore, here, we review this valuable medicinal plant in terms of botany and taxonomy, geographical distribution, traditional medicinal uses, active compounds, and pharmacological properties.

\section{Materials and Methods}

In this review, we deeply searched all the relevant works of literature related to botany, traditional/medicinal application, phytochemicals, safety evaluation, and pharmacological attributes of C. xanthorrhiza. To collect all published data about this species, we used international and local scientific databases including but not limited to PubMed, Scopus, Google Scholar, Web of Science, SINTA, ScienceDirect, and Wiley Online for all accessible papers. Several key terms were used: ("Curcuma xanthorrhiza" OR "Temulawak" OR "Javanese Turmeric") AND ("Botany" OR "Medicinal application" OR “Traditional uses" OR “Toxicity" OR "Pharmacological properties" OR "Biological attributes" OR “Active compounds" OR "Diseases treated” OR "Herbal medicinal use"). Published scientific reports on C. xanthorrhiza in different languages (Bahasa, Malay, and English) were cited in this study. Secondary data were collected and examined, and conclusions were made appropriately.

\section{Botanical Description}

C. xanthorrhiza is an annual plant that grows in clumps and has a pseudostem (2-2.5 $\mathrm{m}$ in height) (Figure 1). Each colony consists of several plants (tillers as much 3 to 9 plants), and each plant has 2-9 leaves. C. xanthorrhiza leaves are long and quite wide $(50-55 \mathrm{~cm}$ long leaves with a width of about $18 \mathrm{~cm}$ ) [25]. C. xanthorrhiza flowers continuously throughout the year alternately coming out of the rhizome. The length of the flower stalk is about $3 \mathrm{~cm}$, and the flower arrangement (inflorescentia) reaches $1.5 \mathrm{~cm}$. One armpit consists of 3-4 flowers. Flower stalks are slim and hairy with a length of $4-37 \mathrm{~cm}$. The grain is flower-shaped, elongated round whose length can reach $23 \mathrm{~cm}$. C. xanthorrhiza flowers have many protective leaves whose length exceeds or sometimes is proportional to the length of the flower crown. Flowers bloom in the morning and wither in the afternoon [26]. The shape of the parent rhizome of C. xanthorrhiza is oval round like an egg, while the shape of branch rhizome found on the side part is elongated. Each plant has approximately 3-4 branch rhizomes. C. xanthorrhiza has a fibrous root system with a root length of about $2.5 \mathrm{~cm}$ with irregular location [25].

\section{Taxonomy and Geographic Distribution}

C. xanthorrhiza Roxb. is an Indonesian original plant which belongs to the Zingiberaceae family and is found in many tropical regions (Figure 2). Besides being known as Temulawak or Javanese turmeric, C. xanthorrhiza has several regional names such as koneng gede (Sundanese), temu labak (Madurese), tommo (Bali), tommon (South Sulawesi), and karbanga (Ternate). This plant can grow in the lowlands to an altitude of $2500 \mathrm{~m}$ above sea level [27]. In Indonesia, this plant is widespread and cultivated in almost all major islands such as Java, Sumatra, Kalimantan, Sulawesi, and Maluku. In addition, C. xanthorrhiza has also been cultivated in several Southeast Asian countries such as Malaysia, Thailand, the Philippines, and Vietnam [1, 2]. In addition, cultivars may also be found in China, India, Japan, and Korea.

\section{Ethnomedicinal Uses}

In Indonesia, C. xanthorrhiza is a very well-known herb and has been widely applied by various tribes to treat various diseases (Table 1). Some traditional uses of C. xanthorrhiza are to overcome lack of appetite, constipation, hemorrhoid, acne, diarrhea, and seizure medication, to destroy gallstones, to treat kidney and liver diseases, rheumatic pain, rheumatism, and arthritis, and to treat thrush and vaginal discharge [39]. C. xanthorrhiza (Temulawak) has also been exported and utilized in Europe at least since 1963, particularly for the treatment of dyspepsia, infections, and skin and liver illness. Traditionally, C. xanthorrhiza rhizome is usually consumed in the form of fresh, decoction, steeping, powder, and even as food. Industrially, the semifinished product from the rhizome of C. xanthorrhiza is simplicia, starch, essential oil, and extract, while the final industrial products are food and drink, cosmetics, syrup, instant powder, tablets, and capsule. C. xanthorrhiza is also often combined with other medicinal plants into a mixture of jamu (Indonesian herbal medicine) products that have been widely produced commercially in Indonesia. For example, a mixture of C. xanthorrhiza, Curcuma longa Linn. syn., and Zingiber officinale is believed by the Javanese to increase stamina, maintain the immune system, and maintain the health of the digestive system. Furthermore, C. xanthorrhiza with Tinospora cordifolia and Andrographis paniculata is widely used by the people of Sulawesi as a cure for gastric disease [33].

However, our evaluation found that most of those traditional uses have been scientifically examined. Some of the scientifically proven ethnomedical uses of C. xanthorrhiza including the medication of skin disease, acne, and gastrointestinal problems such as dysentery, diarrhea, 

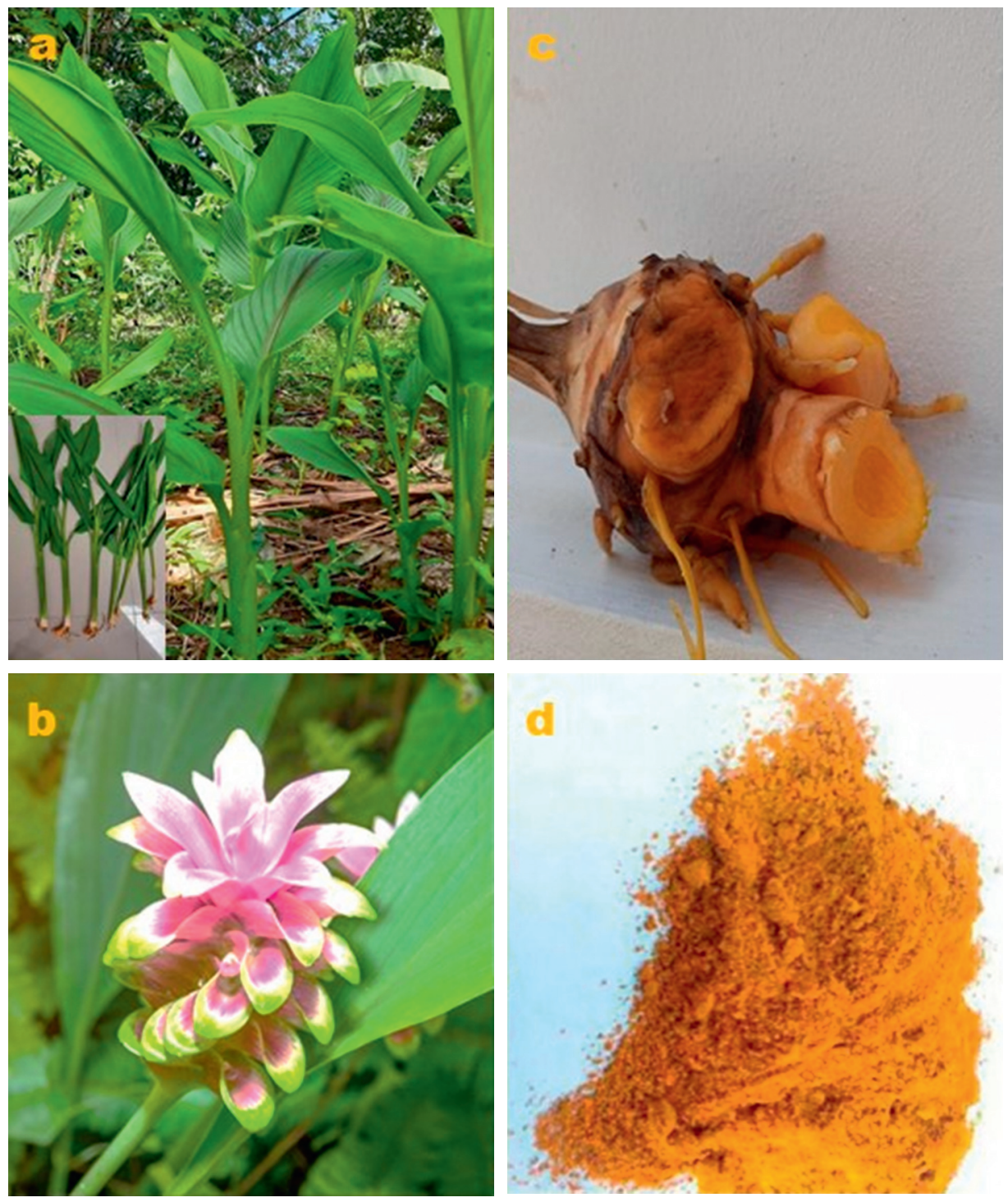

Figure 1: Curcuma xanthorrhiza Roxb. (a) Aerial parts of the plant. (b) Flower. (c) Rhizome. (d) Rhizome powder.

hemorrhoid, constipation, and other digestive system problems are related to its antimicrobial activity (Table 2). The efficacy of C. xanthorrhiza to treat arthritis is probably related to its anti-inflammatory ability [14, 52]. C. xanthorrhiza usage to treat some disorders related to metabolic syndrome such as hypotriglyceridemia has also been scientifically examined [53, 54]. The use of C. xanthorrhiza to cure liver illness has also been tested scientifically $[15,18,55,56]$. We believe that the traditional efficacy of $C$. xanthorrhiza is mostly related to its antimicrobial, antioxidant, and anti-inflammatory capability. Moreover, the efficacy of $C$. xanthorrhiza for malaria treatment has been evaluated preliminarily by heme polymerization inhibition [57]. Surely, this antimalaria activity of C. xanthorrhiza has to be evaluated more comprehensively. On the other hand, we have not found trusted scientific proof indicating $C$. xanthorrhiza effectiveness for the treatment of gynecology-related disorders such as vaginal discharge, postpartum medicine, and postdelivery concoctions. These traditional uses have to be evaluated more using a scientific approach.

\section{Phytochemical Properties of C. xanthorrhiza Roxb}

Chemical studies of C. xanthorrhiza established a foundation of pharmacological research. Substantial works have been done to isolate and purify active compounds from this valuable herb, resulting in the identification of several secondary metabolites (Figure 3). Among these chemicals, curcuminoids and terpenoids are the majority, and they own essential biological properties [19-21]. Furthermore, based on various studies, apparently, the majority in the quantity of the secondary metabolites obtained from the essential oil of C. xanthorrhiza rhizome is xanthorrhizol [58]. The presence of xanthorrhizol in C. xanthorrhiza is speciesdependent, distinguishing C. xanthorrhiza (Temulawak) from C. longa (turmeric) [19, 59]. 


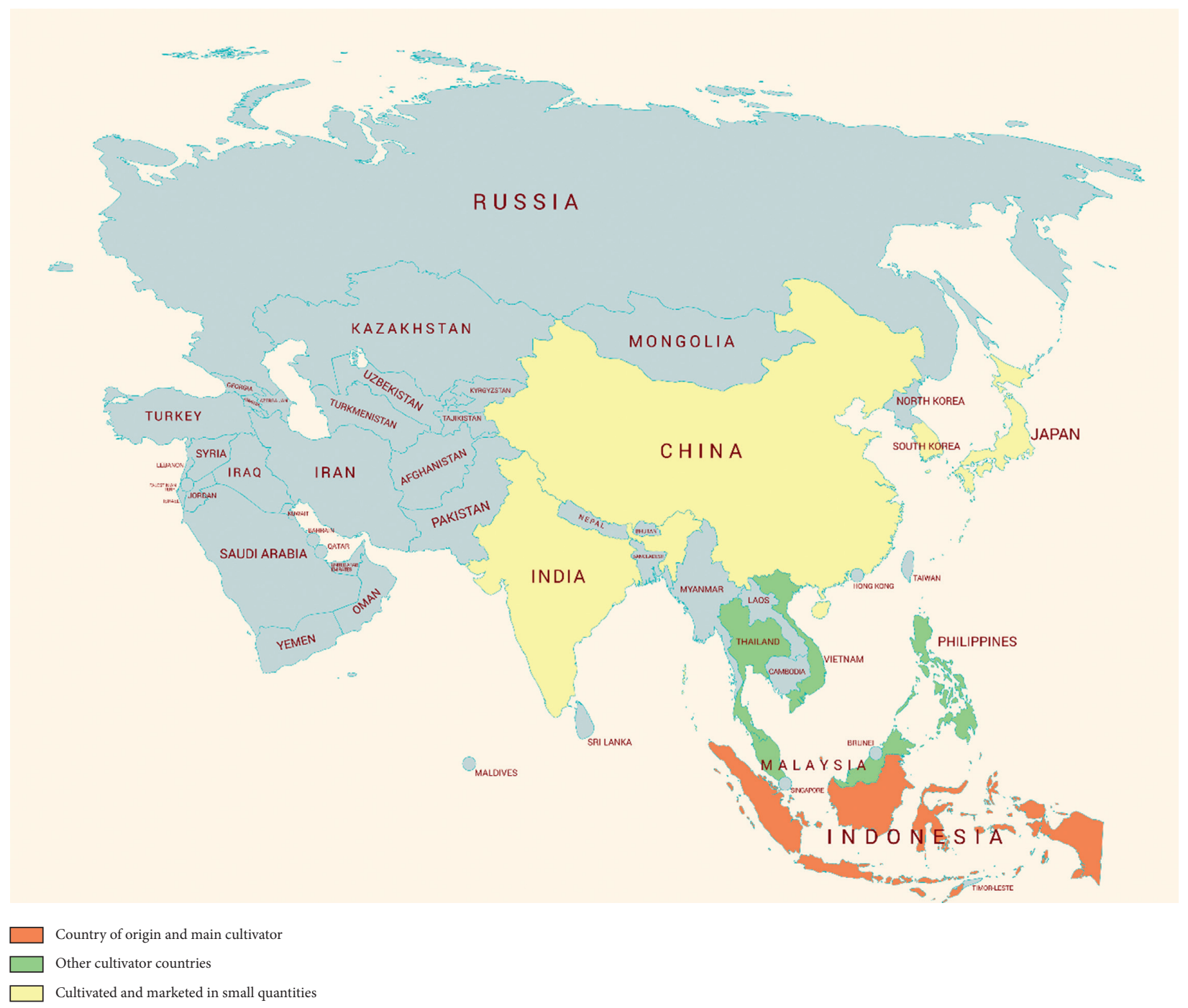

FIgURE 2: Geographic distribution of Curcuma xanthorrhiza Roxb.

TABLE 1: Ethnomedicinal uses of C. xanthorrhiza among Indonesian local communities.

\begin{tabular}{|c|c|c|c|c|}
\hline NO & Local community & Traditional uses & Ethnomedicinal use categories [28] & References \\
\hline 1 & Aceh & Blood booster and malaria medication & Cardiovascular diseases, Parasites & [29] \\
\hline 2 & Bali & Stomach disorders medication & Gastrointestinal problems & [29] \\
\hline 3 & Banjarbaru & $\begin{array}{l}\text { Blood neutralizing, respiratory disorders, } \\
\text { muscular disorders, head disorders, and colds }\end{array}$ & $\begin{array}{l}\text { Metabolic syndromes, Cardiovascular diseases, } \\
\text { Respiratory complaints, Skeletomuscular system }\end{array}$ & [30] \\
\hline 4 & $\begin{array}{l}\text { Enggano, North } \\
\text { Bengkulu }\end{array}$ & Postpartum medicine & Gynaecology & [31] \\
\hline 5 & Kaili Ledo, Sigi & Treating back pain & Skeletomuscular system & {$[32]$} \\
\hline 6 & Madura & Vaginal discharge & Gynaecology & [29] \\
\hline 7 & Sakai, Bengkalis & Appetite booster & Gynaecology & [29] \\
\hline 8 & $\begin{array}{l}\text { Sinjai, South } \\
\text { Celebes }\end{array}$ & Stomach disorders medication & Gastrointestinal problems & {$[33]$} \\
\hline 9 & $\begin{array}{l}\text { Sukolilo, } \\
\text { Surabaya }\end{array}$ & $\begin{array}{c}\text { Maintain health, eliminate fatigue, and maintain } \\
\text { body fitness }\end{array}$ & Metabolic syndromes & {$[34]$} \\
\hline 10 & $\begin{array}{l}\text { Sumowono, } \\
\text { Semarang }\end{array}$ & $\begin{array}{c}\text { Cleaning the digestive tract, increase appetite, } \\
\text { treatment after typhus, post-liver disease, } \\
\text { eliminate fatigue }\end{array}$ & Gastrointestinal problems, metabolic syndromes & {$[35]$} \\
\hline 11 & Surakarta & Wedding potion & Gynaecology & {$[36]$} \\
\hline 12 & $\begin{array}{l}\text { Urug, Sukajaya, } \\
\text { Bogor }\end{array}$ & Postdelivery concoctions & Gynaecology & {$[37]$} \\
\hline 14 & West Java & Treating jaundice, flatulence, urinary stones & $\begin{array}{l}\text { Metabolic syndromes, gastrointestinal } \\
\text { problems, urology }\end{array}$ & {$[29,38]$} \\
\hline
\end{tabular}


TABLe 2: Antibacterial, antifungal, and anti-insecticidal activities of C. xanthorrhiza rhizome extract.

\begin{tabular}{|c|c|c|c|c|c|c|}
\hline No & $\begin{array}{l}\text { Potential } \\
\text { Disease } \\
\text { category }\end{array}$ & Extract type & Dose concentration & Tested species & Effect & Reference \\
\hline \multicolumn{7}{|c|}{ Antibacterial } \\
\hline \multirow{2}{*}{1} & \multirow{2}{*}{ Dental plaque } & Pure xanthorrhizol & $5 \mu \mathrm{mol} / \mathrm{L}$ & $\begin{array}{c}\text { Streptococcus mutans } \\
\text { ATCC } 25175\end{array}$ & $\begin{array}{l}\text { Complete inhibition of } \\
\text { biofilm formation }\end{array}$ & {$[40]$} \\
\hline & & $\begin{array}{c}70 \% \text { ethanol rhizome } \\
\text { extract }\end{array}$ & MIC: $0.1 \%(w / v)$ & $\begin{array}{l}\text { Streptococcus mutans } \\
\text { type F (MUI) }\end{array}$ & $\begin{array}{l}\text { Bacterial growth } \\
\text { inhibition }\end{array}$ & {$[41]$} \\
\hline \multirow{7}{*}{2} & \multirow{7}{*}{$\begin{array}{l}\text { Food-borne } \\
\text { illness }\end{array}$} & \multirow{6}{*}{ Pure xanthorrhizol } & $\begin{array}{c}\text { MIC: } 8 \mu \mathrm{g} / \mathrm{ml} ; \text { MBC: } \\
16 \mu \mathrm{g} / \mathrm{ml}\end{array}$ & $\begin{array}{c}\text { Bacillus cereus ATCC } \\
21772\end{array}$ & $\begin{array}{l}\text { Treatment at } 4 \mathrm{x} \text { MIC } \\
\text { reduced viable cells by } \\
\text { at least } 6 \text { to } 8 \log \text { in } 4 \mathrm{~h}\end{array}$ & {$[42]$} \\
\hline & & & $\begin{array}{c}\text { MIC: } 16 \mu \mathrm{g} / \mathrm{ml} ; \text { MBC: } \\
32 \mu \mathrm{g} / \mathrm{ml}\end{array}$ & $\begin{array}{c}\text { Clostridium } \\
\text { perfringens ATCC } 3624\end{array}$ & $\begin{array}{l}\text { Treatment at } 4 \mathrm{x} \text { MIC } \\
\text { reduced viable cells by } \\
\text { at least } 6 \text { to } 8 \log \text { in } 4 \mathrm{~h}\end{array}$ & {$[42]$} \\
\hline & & & $\begin{array}{c}\text { MIC: } 8 \mu \mathrm{g} / \mathrm{ml} ; \mathrm{MBC}: \\
16 \mu \mathrm{g} / \mathrm{ml}\end{array}$ & $\begin{array}{c}\text { Listeria monocytogenes } \\
\text { ATCC } 15313\end{array}$ & $\begin{array}{l}\text { Treatment at } 4 \mathrm{x} \text { MIC } \\
\text { reduced viable cells by } \\
\text { at least } 6 \text { to } 8 \log \text { in } 4 \mathrm{~h}\end{array}$ & {$[42]$} \\
\hline & & & $\begin{array}{c}\text { MIC: } 8 \mu \mathrm{g} / \mathrm{ml} ; \text { MBC: } \\
16 \mu \mathrm{g} / \mathrm{ml}\end{array}$ & $\begin{array}{c}\text { Staphylococcus aureus } \\
\text { KCCM } 11764\end{array}$ & $\begin{array}{l}\text { Treatment at } 4 \mathrm{x} \text { MIC } \\
\text { reduced viable cells by } \\
\text { at least } 6 \text { to } 8 \log \text { in } 4 \mathrm{~h}\end{array}$ & {$[42]$} \\
\hline & & & $\begin{array}{c}\text { MIC: } 16 \mu \mathrm{g} / \mathrm{ml} ; \text { MBC: } \\
16 \mu \mathrm{g} / \mathrm{ml}\end{array}$ & $\begin{array}{c}\text { Salmonella } \\
\text { typhimurium KCCM } \\
11862\end{array}$ & $\begin{array}{l}\text { Treatment at } 4 \mathrm{x} \text { MIC } \\
\text { reduced viable cells by } \\
\text { at least } 6 \text { to } 8 \log \text { in } 4 \mathrm{~h}\end{array}$ & {$[42]$} \\
\hline & & & $\begin{array}{c}\text { MIC: } 8 \mu \mathrm{g} / \mathrm{ml} ; \mathrm{MBC}: \\
16 \mu \mathrm{g} / \mathrm{ml}\end{array}$ & $\begin{array}{c}\text { Vibrio } \\
\text { parahaemolyticus } \\
\text { ATCC } 17802\end{array}$ & $\begin{array}{l}\text { Treatment at } 4 \mathrm{x} \text { MIC } \\
\text { reduced viable cells by } \\
\text { at least } 6 \text { to } 8 \log \text { in } 4 \mathrm{~h}\end{array}$ & {$[42]$} \\
\hline & & $\begin{array}{c}70 \% \text { ethanol rhizome } \\
\text { extract }\end{array}$ & MIC: $2.0 \%(w / v)$ & $\begin{array}{c}\text { Bacillus cereus ATCC } \\
11778\end{array}$ & $\begin{array}{c}\text { Bacterial growth } \\
\text { inhibition }\end{array}$ & {$[41]$} \\
\hline 3 & Skin diseases & $\begin{array}{c}70 \% \text { ethanol rhizome } \\
\text { extract }\end{array}$ & MIC: $0.1 \%(w / v)$ & $\begin{array}{c}\text { Staphylococcus aureus } \\
\text { ATCC } 25923\end{array}$ & $\begin{array}{l}\text { Bacterial growth } \\
\text { inhibition }\end{array}$ & {$[41]$} \\
\hline 4 & $\begin{array}{l}\text { Infectious } \\
\text { diseases }\end{array}$ & $\begin{array}{l}\text { 96\% ethanol rhizome } \\
\text { extract }\end{array}$ & $\begin{array}{l}100 \% \text { extract } \\
\text { concentration }\end{array}$ & $\begin{array}{c}\text { Staphylococcus } \\
\text { epidermidis ATCC } \\
12228\end{array}$ & $\begin{array}{c}\text { Showed average } \\
\text { inhibition zone } \\
\text { diameter of } 9.20 \mathrm{~mm}\end{array}$ & {$[43]$} \\
\hline 5 & Pneumonia & $\begin{array}{c}100 \% \text { methanol rhizome } \\
\text { extract }\end{array}$ & $\begin{array}{c}\text { MIC: } 1.25 \mathrm{mg} / \mathrm{ml} ; \mathrm{MBC}: \\
2.5 \mathrm{mg} / \mathrm{ml}\end{array}$ & $\begin{array}{l}\text { Klebsiella pneumonia } \\
\text { ATCC } 13773\end{array}$ & $\begin{array}{l}\text { The bacteria } \\
\text { completely killed at } 4 \mathrm{x} \\
\text { MIC for } 15 \mathrm{~min}\end{array}$ & {$[44]$} \\
\hline 6 & Tuberculosis & $\begin{array}{c}96 \% \text { ethanol rhizome } \\
\text { extract }\end{array}$ & $\begin{array}{c}\text { MIC: } 1600 \mu \mathrm{g} / \mathrm{ml} ; \text { MBC: } \\
3200 \mu \mathrm{g} / \mathrm{ml}\end{array}$ & $\begin{array}{l}\text { Mycobacterium } \\
\text { tuberculosis H37Rv }\end{array}$ & $\begin{array}{l}\text { Bacterial growth } \\
\text { inhibition }\end{array}$ & {$[44]$} \\
\hline \multirow{2}{*}{7} & \multirow{2}{*}{ Pulp necrosis } & \multirow{2}{*}{ Essential oil extract } & \multirow{2}{*}{$\begin{array}{l}25 \%-100 \% \text { extract } \\
\text { concentration }\end{array}$} & Enterococcus faecalis & $\begin{array}{l}\text { Inhibition zone: } \\
8-11 \mathrm{~mm} \text { (medium } \\
\text { level antibacterial) }\end{array}$ & {$[45]$} \\
\hline & & & & $\begin{array}{l}\text { Fusobacterium } \\
\text { nucleatum }\end{array}$ & $\begin{array}{l}\text { Inhibition zone: } \\
8-11 \mathrm{~mm} \text { (medium } \\
\text { level antibacterial) }\end{array}$ & {$[45]$} \\
\hline 8 & Diarrhea & $\begin{array}{l}96 \% \text { ethanol rhizome } \\
\text { extract + nanoparticles }\end{array}$ & $500 \mu \mathrm{g} / \mathrm{ml}$ & Escherichia coli & $\begin{array}{l}\text { Bacterial growth } \\
\text { inhibition }\end{array}$ & {$[46]$} \\
\hline 9 & Typhus & $\begin{array}{l}96 \% \text { ethanol rhizome } \\
\text { extract + nanoparticles }\end{array}$ & $500 \mu \mathrm{g} / \mathrm{ml}$ & Salmonella typhi & $\begin{array}{l}\text { Bacterial growth } \\
\text { inhibition }\end{array}$ & {$[46]$} \\
\hline & & $\begin{array}{l}96 \% \text { ethanol rhizome } \\
\text { extract + nanoparticles }\end{array}$ & $500 \mu \mathrm{g} / \mathrm{ml}$ & Bacillus subtilis & $\begin{array}{l}\text { Bacterial growth } \\
\text { inhibition }\end{array}$ & {$[46]$} \\
\hline 10 & Acne & $\begin{array}{c}\text { Essential oil of flower } \\
\text { bract }\end{array}$ & $\begin{array}{c}\text { MIC: } 1 \mathrm{mg} / \mathrm{ml} ; \text { MBC: } \\
3 \mathrm{mg} / \mathrm{ml}\end{array}$ & $\begin{array}{c}\text { Propionibacterium } \\
\text { acnes }\end{array}$ & $\begin{array}{l}\text { Bacterial growth } \\
\text { inhibition }\end{array}$ & {$[47]$} \\
\hline \multicolumn{7}{|c|}{ Antifungal } \\
\hline 11 & $\begin{array}{l}\text { Nosocomial } \\
\text { infections }\end{array}$ & Pure xanthorrhizol & $8 \mu \mathrm{g} / \mathrm{mL}$ & Candida albicans & $\begin{array}{c}\text { Inhibition of biofilm } \\
\text { formation and conidial } \\
\text { germination }\end{array}$ & {$[48]$} \\
\hline
\end{tabular}


TABle 2: Continued.

\begin{tabular}{|c|c|c|c|c|c|c|}
\hline No & $\begin{array}{l}\text { Potential } \\
\text { Disease } \\
\text { category }\end{array}$ & Extract type & Dose concentration & Tested species & Effect & Reference \\
\hline 12 & $\begin{array}{l}\text { Hospital- } \\
\text { acquired } \\
\text { infection }\end{array}$ & Pure xanthorrhizol & $\begin{array}{c}\text { MIC: } 1.0-10 \mathrm{mg} / \mathrm{l} ; \mathrm{MFC}: \\
15 \mathrm{mg} / \mathrm{ml} \\
\text { MIC: } 2.0-8.0 \mathrm{mg} / \mathrm{l} ; \mathrm{MFC}: \\
12.5 \mathrm{mg} / \mathrm{ml} \\
\text { MIC: } 2.5-7.5 \mathrm{mg} / \mathrm{l} ; \mathrm{MFC}: \\
10 \mathrm{mg} / \mathrm{ml} \\
\text { MIC: } 2.5-25 \mathrm{mg} / \mathrm{l} ; \mathrm{MFC}: \\
30 \mathrm{mg} / \mathrm{ml} \\
\text { MIC: } 2.0-8.0 \mathrm{mg} / \mathrm{l} ; \mathrm{MFC}: \\
10 \mathrm{mg} / \mathrm{ml}\end{array}$ & $\begin{array}{c}\text { Candida glabrata } \\
\text { Candida } \\
\text { guilliermondii } \\
\text { Candida krusei } \\
\text { Candida parapsilosis } \\
\text { Candida tropicalis }\end{array}$ & $\begin{array}{l}\text { Able to kill the } \\
\text { Candida strains }\end{array}$ & [40] \\
\hline 13 & $\begin{array}{l}\text { Filamentous } \\
\text { fungal } \\
\text { infections }\end{array}$ & Pure xanthorrhizol & $\begin{array}{c}\text { MIC: } 2.0 \mu \mathrm{g} / \mathrm{ml} \text {; MFC: } \\
4.0 \mu \mathrm{g} / \mathrm{ml} \\
\text { MIC: } 2.0 \mu \mathrm{g} / \mathrm{ml} \text {; MFC: } \\
4.0 \mu \mathrm{g} / \mathrm{ml} \\
\text { MIC: } 2.0 \mu \mathrm{g} / \mathrm{ml} \text {; MFC: } \\
4.0 \mu \mathrm{g} / \mathrm{ml} \\
\text { MIC: } 4.0 \mu \mathrm{g} / \mathrm{ml} ; \text { MFC: } \\
8.0 \mu \mathrm{g} / \mathrm{ml} \\
\text { MIC: } 1.0 \mu \mathrm{g} / \mathrm{ml} ; \text { MFC: } \\
2.0 \mu \mathrm{g} / \mathrm{ml} \\
\text { MIC: } 1.0 \mu \mathrm{g} / \mathrm{ml} ; \text { MFC: } \\
2.0 \mu \mathrm{g} / \mathrm{ml}\end{array}$ & $\begin{array}{c}\text { Aspergillus flavus } \\
\text { Aspergillus fumigatus } \\
\text { Aspergillus niger } \\
\text { Fusarium oxysporum } \\
\text { Rhizopus oryzae } \\
\text { Trichophyton } \\
\text { mentagrophytes }\end{array}$ & $\begin{array}{l}\text { Inhibition the conidial } \\
\text { germination }\end{array}$ & [49] \\
\hline $\begin{array}{l}14 \\
15\end{array}$ & $\begin{array}{l}\text { Skin and nail } \\
\text { infections }\end{array}$ & $\begin{array}{l}\text { Acetone extract and } \\
\text { chloroform fractions }\end{array}$ & MIC:12.5-25.0 $\mu \mathrm{g} / \mathrm{mL}$ & $\begin{array}{l}\text { Epidermophyton sp. } \\
\text { Trichophyton rubrum }\end{array}$ & $\begin{array}{l}\text { Significant growth } \\
\text { inhibition }\end{array}$ & [50] \\
\hline 16 & Penicilliosis & $\begin{array}{l}\text { Acetone extract and } \\
\text { chloroform fractions }\end{array}$ & MIC:12.5-25.0 $\mu \mathrm{g} / \mathrm{mL}$ & Penicillium sp. & $\begin{array}{l}\text { Significant growth } \\
\text { inhibition }\end{array}$ & [50] \\
\hline \multicolumn{7}{|c|}{ Anti-insecticidal } \\
\hline 17 & Agriculture pest & Pure xanthorrhizol & $\begin{aligned} \mathrm{LD} 50= & 6.92-8.13 \mu \mathrm{mol} / \\
& \mathrm{kg} \text { fr.wt }\end{aligned}$ & Spodoptera littoralis & $\begin{array}{l}\text { Significant mortality of } \\
\text { the larvae }\end{array}$ & {$[51]$} \\
\hline
\end{tabular}

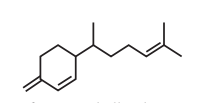

$\beta$-Sesquiphellandrene
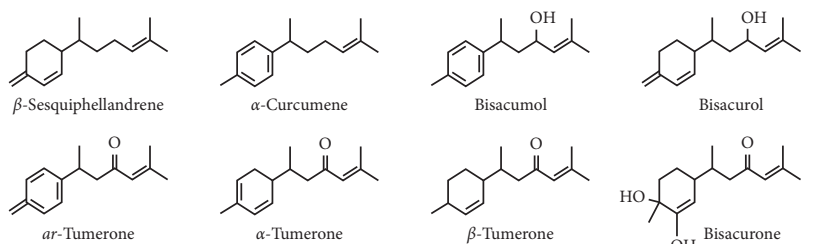<smiles>CC(C)=CC(=O)CC(C)C1CCC(C)CC1</smiles><smiles>CC(C)=CC(=O)CC(C)C1C=C(C)C(C)(O)CC1</smiles><smiles>CC(C)=CCCC(C)c1ccc(C)c(O)c1</smiles><smiles>CC(C)=CCC(C)C1CC=C(C)CC1</smiles><smiles>Cc1ccc(C(C)CC=CC(C)(C)O)cc1O</smiles>

$\mathrm{X}$ anthorrizol<smiles>COc1cc(C(C)CCC=C(C)C)c(Cl)cc1C</smiles>

$\beta$-Bisabolol<smiles>COc1ccc(C(C)CCCC(C)(C)O)cc1</smiles><smiles>COc1cc(C=O)ccc1O</smiles><smiles>CC(=O)c1cc(O)ccc1C</smiles><smiles>Cc1ccc(C(C)CCC2OC2(C)C)cc1O</smiles>

12, 13-Epoxyxanthorrhizol 3-Hydroxy-6- Champor methylacetophenone 10, 11-dihydroxyxanthorrhizo 3-O- $\beta$-D-glucopyranoside

(-)-Curcuhydroquinone $2,5-$ di-O- $\beta$-D-glucopyranoside
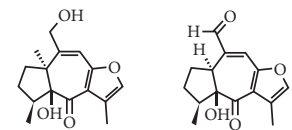

Zedoardiol
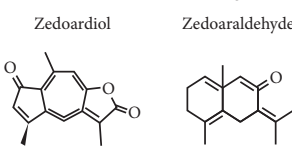

Guaia-1(10), 3, 5, 7(11), 8pentaene-2-on-12, 8-olid
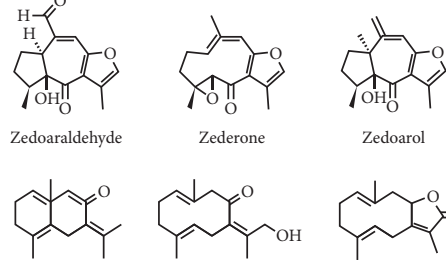
Germacrone 13 -Hydroxygermacron 13-Hydroxygermacrone

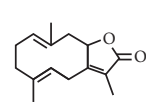
Gelchomanolide

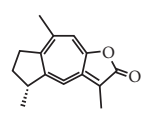

Gweicurculactone

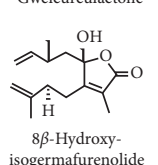

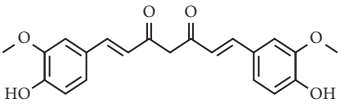

Dihydrocurcumin<smiles>COc1cc(CCC(=O)CC(O)CCc2ccc(O)c(OC)c2)ccc1O</smiles><smiles>COc1cc(/C=C/C(=O)CC(=O)/C=C/c2ccc(O)cc2)ccc1O</smiles><smiles>COc1cc(CCC(O)CC(O)CCc2ccc(O)c(OC)c2)ccc1O</smiles>

1, 7-Bis(4-hydroxy-3-methoxyphenyl)-heptane-3, 5-diol
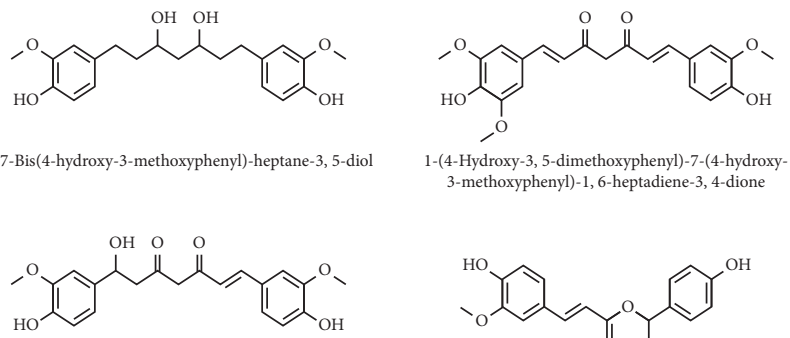

1-Hydroxy-1, 7-bis(4-hydroxy-3methoxypheny1)-6-heptene-3, 5-dione
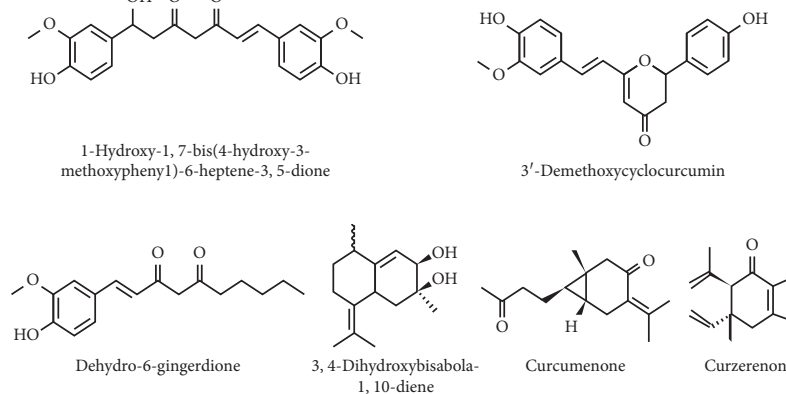

3'-Demethoxycyclocurcumin

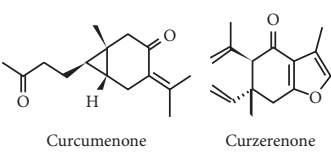

Figure 3: Isolated active compounds from Curcuma xanthorrhiza Roxb. 
However, there is a difference in metabolite profiles of C. xanthorrhiza rhizome in diverse fractions (methanol, ethyl acetate, chloroform, and hexane) of ethanol extract. Terpenoids such as xanthorrhizol were prominent in the hexane soluble fraction. Large amounts of phenolic compounds, such as curcuminoids, were present in ethyl acetate soluble fractions. Amino acids, including methionine, phenylalanine, tryptophan, valine, alanine, lysine, and leucine, were discovered in the methanol fraction. The hexane, chloroform, and ethyl acetate fractions did not have carbohydrate and amino acid signals [60]. This is because the difference in the polarity of the solvent results in the discrepancy in the retention of different types of plant compounds. Below are the major group of secondary metabolites present in the rhizome of C. xanthorrhiza.

6.1. Terpenoids. Various studies have shown that C. xanthorrhiza contains a variety of terpenoids, especially bisabolane sesquiterpenoids. Earlier, at least 50 bisabolane sesquiterpenes were discovered from the genus Curcuma, particularly its turmeric rhizome [61]. Sesquiterpene compounds that have been successfully isolated and characterized from C. xanthorrhiza are bisacurone, bisacumol, bisacurol, curlone [62], $\alpha$-curcumene, ar-turmerone, xanthorrhizol, germacrone, $\beta$-curcumene, $\beta$-sesquiphellandrene, curzerenone, $\alpha$-turmerone, $\beta$-turmerone [62], $(7 R, 10 R)$-10,11-dihydro-10,11-dihydroxy-xanthorrhizol 3$O$ - $\beta$-D-glucopyranoside, (-)-curcuhydroquinone 2,5-di-O$\beta$-D-glucopyranoside, 13-hydroxy-xanthorrhizol, 12,13-epoxy-xanthorrhizol, $\beta$-bisabolol [61], zedoardiol, 3,4-dihydroxybisabola-1,10-diene, zedoarol, guaia-1(10),3,5,7(11),8pentaene-2-on-12,8-olide, zederone, curcumenone [21], zedoaraldehyde, gweicurculactone, 13-hydroxygermacrone, germacrone, gelchomanolide, and $8 \beta$-hydroxy-isogermafurenolide [63]. In addition to sesquiterpenes, C. xanthorrhiza also contains monoterpene which has been successfully isolated, namely, camphor [19].

6.2. Curcuminoids. Curcuminoids are natural polyphenol compounds with a linear diarylheptanoid structure. A curcuminoid of C. xanthorrhiza mostly consists of dicinnamoylmethane derivatives. Various curcuminoids have been successfully obtained and categorized from the rhizome of C. xanthorrhiza such as octahydrocurcumin, 1hydroxy-1,7-bis(4-hydroxy-3-methoxypheny1)-6-heptene3,5-dione, dihydrocurcumin, hexahydrocurcumin, curcumin [62], monodemethoxy curcumin, bis-demethoxy curcumin [19], 1-(4-hydroxy-3,5-dimethoxyphenyl)-7-(4hydroxy-3-methoxyphenyl)-1,6-heptadiene-3,4-dione [13], 3-demethoxycyclocurcumin, and 1,7-bis(4-hydroxy-3methoxyphenyl)-heptane-3,5-diol [60].

6.3. Other Phenolic Compounds. In addition to terpenoids and curcuminoids, several other chemical compounds have also been successfully detected in the rhizome of C. xanthorrhiza such as vanillin [21], 3-hydroxy-6-methylacetophenone, and dehydro-6-gingerdione [63]. However, 13-hydroxy-xanthorrhizol and 12,13-epoxy-xanthorrhizol were identified beforehand from Curcuma longa rhizomes. Meanwhile, 3-hydroxy-6-methylacetophenone alluded as a residual product of synthetic reactions $[64,65]$, but Zhang et al. [63] found it for the first time as a nature-derived metabolite. Moreover, Zhang et al. [63] also announced the first identification of dehydro-6-gingerdione from C. xanthorrhiza, which was previously isolated from Zingiber officinale [66].

Mostly, the active compounds above were isolated from the rhizome of C. xanthorrhiza. However, other parts of C. xanthorrhiza are also probably containing a variety of important secondary metabolites, for example, the flower bract, which is proven to contain several active compounds, namely, xanthorrhizol (16.13\%), $\alpha$-curcumene (15.12\%), $\beta$-elements (4.60\%), trans-caryophyllene (3.48\%), $\beta$-farnesene $(0.29 \%)$, camphor $(0.21 \%)$, and isoborneol (0.04\%) [47].

\section{Biotechnological Production of C. xanthorrhiza Roxb}

High market demand for C. xanthorrhiza as one of the important sources of herbal medicine ingredients both in Indonesia and in other countries triggers the implementation of several studies on the production technology of C. xanthorrhiza plants which are effective, efficient, and safe and of high quality. One of them is micropropagation through plant tissue culture techniques. Several combinations of growth media and hormones have been used as a protocol for micropropagation of C. xanthorrhiza seedlings including a combination of MS media + IBA + BAP [67], a combination of MS media + BA + NAA [68], and a combination of MS media + BAP for microrhizome formation [69]. The above studies only use MS medium as their propagation protocol. Therefore, to further elaborate the study in order to find the most optimum growth condition for C. xanthorrhiza, it is necessary to try another type of growth media such as woody plant medium (WPM), Linsmaier and Skoog (LS) medium, Gamborg $\left(\mathrm{B}_{5}\right)$ medium, and Nitsch and Nitsch (NN) medium. In addition, to obtain high-quality clone results, it is necessary to test the genetic fidelity, chemical property, and physiological characteristics between the mother plant and the clone. Another strategy that has been carried out to increase the average number of shoots and roots of C. xanthorrhiza is by inducing polyploidy which can be achieved by colchicine feeding [23]. Natural materials that are easily found such as coconut water are also proven to stimulate the growth of in vitro seedling of C. xanthorrhiza and contain more chlorophyll compared to C. xanthorrhiza that grows conventionally [70]. In addition, efforts have also been made to increase the bioactive compound content within C. xanthorrhiza. One of the ways is by using elicitation technique by yeast extract which is proven to increase the content of xanthorrhizol [23]. However, all of the above studies are still preliminary, and there is still plenty of research space that can be explored for optimum propagation and production of C. xanthorrhiza including the enhancement of its phytochemicals content by well-known elicitors such as methyl jasmonate and salicylic 
acid, as well as its scale-up production system using bioreactor.

\section{Pharmacological Activities of C. xanthorrhiza}

Different biological activities of C. xanthorrhiza have been studied using various approaches. Many of the examined pharmacological attributes bolster the unconfirmed ethnomedicinal application of this herb. Pharmacological reports in detail are explained hereinafter.

8.1. Antioxidant Activity. Aerobic metabolism in the human body could produce free radicals (e.g., nitric oxide, superoxide, and hydroxyl radicals) and other reactive species (e.g., peroxynitrite, hydrogen peroxide, and hypochlorous acid) [71]. Free radical reactions can cause harmful degenerative illness including degenerative eye disorder, senile dementia, asthma, diabetes, atherosclerosis, cancer, and inflammatory joint sickness [72]. Antioxidants are compounds that exert synergistic actions in scavenging free radicals by inhibition of oxidation reaction. Some studies reported the potential natural antioxidant activity of $C$. xanthorrhiza extract [73-75]. The antioxidant ability of C. xanthorrhiza has been evaluated using various methods including the DPPH $(1,1$ diphenyl-2-picrihydazi), superoxide anion, ferric reducing antioxidant power (FRAP), and metal bonding activity $[76,77]$.

Rosidi et al. [74] assessed the antioxidant activity of ethanol extract of $C$. xanthorrhiza in the liquid-liquid extraction method in hexane solvent using the DPPH method. The study revealed that the tested extract of C. xanthorrhiza has a relatively active antioxidant activity with an $\mathrm{IC}_{50}$ value of $87.01 \mathrm{ppm}$. Meanwhile, Widyastuti et al. [75] examined the antioxidant properties of C. xanthorrhiza harvested from different locations. The methanol extract of $C$. xanthorrhiza from various places has been assessed for its antioxidant properties along with total phenolic and total flavonoid composition. The result showed that C. xanthorrhiza has potent antioxidant activity and its level is apparently affected by different harvesting areas [75]. The discovery validates the diverse uses and effectiveness of this herb over various traditional areas and populations (Table 1) and gives possible suggestions on the levels of active molecules depending on the location of cultivation. Storage time following the harvesting also affects the antioxidant level of C. xanthorrhiza. The prolonged storage time of C. xanthorrhiza could decrease its antioxidant ability [78]. In addition, the harvesting age of C. xanthorrhiza is another parameter affecting the level of its antioxidant activity. A study by Rosiyani [79] showed that 9-month-old C. xanthorrhiza rhizome possesses greater antioxidant activity compared to 7- or 8-month-old harvesting time. This could happen probably because the curcuminoid content is higher in that of older C. xanthorrhiza. Along with Curcuma longa and Zingiber officinale, the antioxidant activity of methanol extract of C. xanthorrhiza was shown higher than the other seven Zingiberaceae species studied by Akinola et al. [80]. In addition, the antioxidant activity of pure xanthorrhizol from C. xanthorrhiza has been evaluated in copper-mediated isolated human low-density lipoprotein (LDL) oxidation [81] and sturdily reduced human LDL peroxidation in a dose-dependent manner. We recommend that xanthorrhizol could be tested for future experiments in cardiovascular disorders because strong LDL antioxidant properties could lower the risk of heart disorders. Future study of antioxidant test should also be performed in vivo.

We believe that the antioxidant properties of C. xanthorrhiza greatly contribute to its traditional uses. For example, traditionally, C. xanthorrhiza has been utilized as an arthritis medication where one of its major causes is the inflammation reaction within the joint caused by the free radical reaction. The antioxidant ability of $C$. xanthorrhiza in scavenging free radicals could treat this inflammatory joint sickness as reported traditionally. Furthermore, the traditional efficacy of C. xanthorrhiza for skin treatment is also inseparable from this antioxidant ability. The antioxidant activity has been reported to have connected with the prevention of skin aging [82].

However, although the potent antioxidant capability of C. xanthorrhiza was evaluated, it still leaves the fundamental question of whether all free radical scavenging activities are a reflection of the extracts and chemicals being tested and should be further evaluated using a more reliable antioxidant assay method. One of them is by using a more comprehensive in vitro cell-based antioxidant assay approach because it can detect metabolites that play a direct role in the antioxidant pathway and safeguarding cells against oxidative harm [83].

8.2. Antibacterial, Antifungal, and Anti-Insecticidal Activities. The antimicrobial activity of C. xanthorrhiza has been well studied using a number of disease-causing microbes (Table 2). The tested pathogens could cause some serious diseases such as food-borne illness, dental plaque, skin disease, infectious disease, pneumonia, tuberculosis, pulp necrosis, diarrhea, typhus, acne, nosocomial infections, hospital-acquired infection, filamentous fungal infections, nail infection, and penicilliosis (Table 2). Some well-known methods used to evaluate in vitro susceptibility test of C. xanthorrhiza such as NCCLS (M38-A) standard method and biofilm quantification, minimum bactericidal concentration $(\mathrm{MBC})$, minimum inhibitory concentration (MIC), and minimum fungicidal concentration (MFC). Rhizome extract of C. xanthorrhiza, pure xanthorrhizol, and its essential oils are proven to be the potential of inhibiting or killing pathogenic microbes ranging from medium level activity to strong killing ability (Table 2) [40-42, 44-46, 48, 50, 84].

The antimicrobial capability of C. xanthorrhiza is possibly due to its phenolic compound content particularly xanthorrhizol and curcuminoids as the main ingredient. The phenolic compound has been reported to have inhibition action on cell walls or membranes of microbes by altering its cell permeability, resulting in the forfeit of essential molecules such as ATP, RNA, protein, and DNA [85]. Although 
the mode of antimicrobial action of xanthorrhizol has not been comprehensively elucidated, xanthorrhizol possibly has suppression ability on nuclear factor kappa B (NF-kB) and mitogen-activated protein kinase (MAPK) caused by microbial attack [86]. As for curcumin, some of its antimicrobial modes of action were explained by restraint of cytokinesis and bacterial cell multiplication, as well as interruption of bacterial cell wall and membrane, inducing cell lysis [87]. Curcumin was also reported to form electrostatic and/or hydrophobic interplay with cell membrane and wall of fungi resulting in a disarrangement of the membrane [88]. Even though the antibacterial attribute of C. xanthorrhiza seems to work on Gram-positive and some Gram-negative bacteria, it is more powerful than Gram-positive bacteria due to the composition of its cell wall.

Most of those reported microbe-related illnesses are linked up to the traditional uses of C. xanthorrhiza such as treatment of gastrointestinal problems and skin-related disorders. Thus, the reported antimicrobial activity of C. xanthorrhiza supports some of its traditional medicinal benefits. For example, the ability of ethanol extract of C. xanthorrhiza to suppress the growth of Escherichia coli is related to its traditional use for diarrhea treatment. In addition, the capability of its essential oil of flower bract to inhibit Propionibacterium acnes growth is probably related to its traditional usage for the medication acne. However, even if the antibacterial ability of this herb has been explained, their utilization as alternatives to antibiotics still needs pharmacodynamic and pharmacokinetic examination to reveal the mode of action of underlying metabolites.

Furthermore, pure xanthorrhizol isolated from C. xanthorrhiza extract has also reported anti-insecticidal properties against Spodoptera littoralis following its topical application [89]. This discovery opens its future potential for treating agriculture pests.

8.3. Anti-Inflammatory Property. The anti-inflammatory capability of methanol rhizome extract of C. xanthorrhiza has long been investigated on carrageenan-induced edema, vascular permeability caused by acetic acid, and the writhing phenomenon in rats [10]. The extract exhibited anti-inflammatory potential particularly by the presence of germacrone. The anti-inflammatory ability of C. xanthorrhiza probably is also related to its curcuminoid content especially curcumin. Curcumin has more potent anti-inflammatory properties than other curcuminoid derivatives such as demethoxy- or bisdesmethoxy-form [89].

Furthermore, the anti-inflammatory ability of C. xanthorrhiza is indeed also caused by xanthorrhizol as its marker compound. The earliest in vitro anti-inflammatory activity of xanthorrhizol has been reported on lipopolysaccharide-induced mice leukemic monocyte-macrophage cell RAW 264.7 [52]. The study reported the inhibition of prostaglandin E2 (PGE2) and nitric oxide (NO) production by xanthorrhizol, resulting in the reduction of cyclooxygenase-2 (COX-2) and inducible nitric oxide synthase (iNOS), respectively [52]. The result is supported by other anti-inflammatory tests of xanthorrhizol using lipopolysaccharide-activated primary cultured microglial cells [14]. Lim et al. [14] successfully showed that xanthorrhizol could hinder COX-2, iNOS, tumor necrosis factor- $\alpha$ (TNF- $\alpha$ ), and proinflammatory cytokine interleukin-6 (IL-6) in induced microglial cells. Xanthorrhizol has also been studied in vivo using 12-O-tetradecanoylphorbol13-acetate- (TPA-) activated mice severe inflammation specimen and restrains the impact of TPA-activated ornithine decarboxylase (ODC), COX-2, and iNOS expression in mice dermis [90]. According to these findings, xanthorrhizol can be confirmed to be involved in the suppression of IL 6 and TNF- $\alpha$, as well as inhibition of COX-2 and iNOS activation via NF-kB pathway causing PGE2 and NO decrease. Based on preliminary reported data, the hydroxyl group of xanthorrhizol is essential for its pharmacological ability, in that acetylation of the hydroxyl group causes activity loss. However, in-depth future research is necessary to elucidate the structure-function correlation and molecular mode of action of xanthorrhizol.

In the most recent study, Kim et al. [54] reported the anti-inflammatory properties of standardized xanthorrhizol and C. xanthorrhiza extract in a high-fat diet- (HFD-) caused obese mouse. The report suggested the significant inhibition expression of inflammatory cytokines, such as $\mathrm{C}$ reactive protein (CRP), interleukin-1 $\beta$ (IL-1 $\beta)$, IL-6, and TNF- $\alpha$ in muscle (65.2-92.5\%), liver (43.9-84.7\%), and adipose tissue (27.8-82.7\%) [54]. Repression of interleukin$1 \beta$ (IL-1 $\beta$ ) and nuclear factor kappa B (NF-kB) p65 by C. xanthorrhiza extract and xanthorrhizol has also been investigated on lipopolysaccharide- (LPS-) treated human gingival fibroblast-1 cells [91]. This result showed the potential of C. xanthorrhiza extract and xanthorrhizol to suppress LPS-activated oral inflammation. Thus, we believe that C. xanthorrhiza and xanthorrhizol have antiperiodontitis capability. In this research, Kim et al. [91] using xanthorrhizol at concentrations of 1 and $10 \mu \mathrm{M}$ (low and high, respectively). Hence, other concentrations between 1 and $10 \mu \mathrm{g} / \mathrm{ml}$ C. xanthorrhiza or 1 and $10 \mu \mathrm{M}$ xanthorrhizol would have anti-inflammatory and antiosteoclastogenic activities. In addition, these data are reinforced by the ability of C. xanthorrhiza to inhibit the growth of periodontopathogens, such as Streptococcus mutans (Table 2). However, the stimulatory ability of C. xanthorrhiza and xanthorrhizol on osteoblastogenesis or the mechanism of bone development has not been illustrated yet. Hence, further studies on the osteoblastogenic effects and underlying molecular actions of these metabolites in living systems, such as animal models, are required.

Furthermore, some researchers used animal models to examine the anti-inflammatory potential of C. xanthorrhiza and its compounds. However, ethical processes increase the limitation of animal model-research based. Therefore, several in vitro anti-inflammatory approaches are available to elucidate the anti-inflammatory ability of C. xanthorrhiza and its isolated compounds. For example, flow cytometry is a fast and helpful instrument to discover the anti-inflammatory activity of some inflammatory markers together and there should be a useful anti-inflammatory investigation on C. xanthorrhiza. 
8.4. Anticancer and Antitumor Properties. The first preliminary antitumor test of some compounds ( $\beta$-atlantone, $\alpha$-curcumene, ar-turmerone, and xanthorrhizol) from rhizome extract of $C$. xanthorrhiza was performed on sarcoma 180 ascites in rats [92]. Three compounds ( $\alpha$-curcumene, arturmerone, and xanthorrhizol) from this study showed significant antitumor activity evaluated by the packed cell volume method. The antimetastatic and antitumor potential of xanthorrhizol was further assessed in vivo using mice lung-metastasis specimens and a tumor cell development test [93]. Surprisingly, xanthorrhizol significantly suppressed the induction of tumor spots in the lung tissue and the development of the intra-abdominal mass of the tumor. This result is strengthened by the molecular analysis showing that xanthorrhizol could inhibit the expression of COX-2, phosphorylated extracellular signal-regulated kinase (ERK), and matrix metalloproteinase-9 (MMP-9) in metastatic mice [92]. Further assessment of isolated xanthorrhizol from C. xanthorrhiza against the proliferation of cancer cells was performed in combination with curcumin in MDA-MB-231 (human breast cancer cells) [22]. The experiment proved that the application of xanthorrhizol and curcumin exhibited synergistic growth inhibition on MDA-MB-231 cells via activation of apoptosis.

However, the above is not the first study reporting xanthorrhizol ability to induce cell apoptosis. Previous studies also showed that xanthorrhizol was able to activate apoptosis via induction of mitochondrial pathway (p53dependent) in HeLa cervical cancer [94] and HepG2 liver cancer [94]. Within HeLa cervical cancer cells, xanthorrhizol upregulated p53 and Bax but had no effect on Bcl-2 (antiapoptotic protein). This upregulation of $\mathrm{p} 53$ and Bax protein production probably reactivates the sensitivity of cervical cancer cells toward apoptotic stimuli [94]. However, this result is in contrast with those reported by Handayani et al. [95] and Cheah et al. [22], where upregulation of p53 did not affect Bax expression but lowered the Bcl-2 level in HepG2 liver cancer cells and MCF-7 breast cancer. From these findings, xanthorrhizol may have apoptosis induction activity via $\mathrm{p} 53$-regulated mitochondrial pathway in particular cancer cells with diverse regulation on the expression of Bax/ Bcl-2 [86].

8.5. Antidiabetic Properties. The antimetabolic disorder effect of C. xanthorrhiza extract, such as antidiabetic, has been evaluated using both insulin-dependent [53] and noinsulin-dependent diabetic models [54]. Yasni et al. [53] reported the antidiabetic properties of the extract of C. xanthorrhiza in the streptozotocin-activated diabetic mouse. The report suggested that the extract of C. xanthorrhiza extremely lowered the level of serum glucose and triglyceride as compared to cellulose and other tested herbals. C. xanthorrhiza was also found to reduce the ratio of arachidonate to linoleate in the liver phospholipids [53]. In another study using high-fat diet- (HFD-) induced obese rats, Kim et al. [54] found that both xanthorrhizol and C. xanthorrhiza extracts could exceptionally suppress postprandial blood glucose content in HFD-induced obese mouse. Moreover, xanthorrhizol and C. xanthorrhiza extracts are also able to reduce triglyceride (TG), glucose, free fatty acid (FFA), and insulin composition in serum [54]. According to this study, xanthorrhizol and C. xanthorrhiza extracts may suppress and cure noninsulin-dependent diabetes, which is mostly caused by obesity-activated resistance of insulin.

8.6. Skin Care. The study of anti-skin aging properties of xanthorrhizol was performed by evaluating its effect on the expression of MMP-1 and type-1 procollagen in UV-irradiated human skin fibroblasts [96]. Matrix metalloproteinases (MMPs) are one responsible factor mediating the UV-induced skin aging that is upregulated by UV irradiation. Meanwhile, type-1 collagen is the main builder of the skin dermis, and the degradation of this structural protein could lead to skin aging problems. Xanthorrhizol isolated from C. xanthorrhiza was proven to be efficacious for decreasing the expression level of MMP-1 and increasing type-1 procollagen expression [96]. Xanthorrhizol's ability to suppress the MMP-1 expression and increase type-1 procollagen expression is even better than the effect of a natural antiaging agent known as epigallocatechin 3-O-gallate (EGCG) [95].

In addition, skin-caring effects of C. xanthorrhiza were also evaluated using its flower bract extract. Batubara et al. [47] reported that methanol extract of C. xanthorrhiza flower bract could suppress the growth of acne-causing microbe Propionibacterium acnes and its ethyl acetate flower bract extract could suppress tyrosinase and lipase activities. $\alpha$-curcumene and xanthorrhizol of C. xanthorrhiza flower bract extract are two main compounds responsible for lipase activity inhibition and Propionibacterium acnes growth suppression, respectively [47]. This study shows that C. xanthorrhiza flower bract extract is a potent natural skincare and whitening agent. However, this study did not assess dose-response effects. Moreover, since the study of flower bract extract of C. xanthorrhiza is still limited, a follow-up study is required to reveal other active molecules within the flower bract extract that is responsible for the skin-caring activity as well as its possible structure-function relationship.

8.7. Hepatoprotective Activity. Oral application of C. xanthorrhiza in mice and rats has been shown to have hepatoprotective effects from a number of hepatotoxic causes, such as acetaminophen, galactosamine, and carbon tetrachloride, as indicated by extreme alleviation of serum transaminases [12, 97]. This hepatoprotective activity is regarded due to the presence of its antioxidant compounds, as well as its capability to reduce the activation of proinflammatory cytokines. Kim et al. $[15,56]$ found that oral feeding of $200 \mathrm{mg}$ xanthorrhizol weakened cisplatin-induced hepatotoxicity and nephrotoxicity in mice (cisplatin is frequently applied in chemotherapy). Its likely mode of action is by attenuation of c-Jun N-terminal kinases (JNKs) phosphorylation. The above effect shows that C. xanthorrhiza has the potential to safeguard the liver 
against various hepatotoxins as also reported by many of its traditional uses. This hepatoprotective activity was further supported by other reports showing that C. xanthorrhiza could reduce liver triglyceride level and serum triglyceride content $[18,55]$.

\section{Safety Evaluation (Cytotoxicity)}

Oral administration of up to $2 \mathrm{~g} / \mathrm{kg}$ body weight of aqueous extract of C. xanthorrhiza showed no indication of toxicity in mice or rats [97]. A previous study also showed that no mortality was found following a single oral application of pure xanthorrhizol to mice at $500 \mathrm{mg} / \mathrm{kg}$ [98]. In the most recent report, the toxicity level of ethanol extract of C. xanthorrhiza has been evaluated orally on the hematological and male reproduction system of mice [99]. The obtained results suggested that oral application of C. xanthorrhiza had no significant effect on hematological and spermatogenic changes. Hence, C. xanthorrhiza did not give a toxic effect on the hematological characteristics and reproductive system of male mice [99]. This result is in contrast to C. zedoaria Roscoe. causing a notable decrease in $\mathrm{RBC}, \mathrm{Hb}$ level, and spermatozoa quality [99].

Although in vivo tests of aqueous extract of C. xanthorrhiza (at dose $2 \mathrm{~g} / \mathrm{kg}$ ) and pure xanthorrhizol ( $500 \mathrm{mg} / \mathrm{kg}$ dosage) are shown to be nontoxic to mice, prior to clinical trials, we propose that in vivo mice pharmacokinetic and pharmacodynamic tests must be performed in depth. The logical reason is that in the in vivo systems all the processes of absorption, distribution, metabolism, and elimination of a compound are much more complex than the in vitro systems [100]. Pharmacokinetic evaluation is needed to increase the efficacy of the extract or compound being tested, as well as to lessen the level of toxicity. In a complex living system, the connection between the concentration of the drug at the action area and its pharmacological reaction could be predicted via pharmacodynamics methods [100]. In addition, scientific data on the mutagenic potential of C. xanthorrhiza, genotoxicity, carcinogenicity, and even reproductive toxicity of C. xanthorrhiza is still limited. Therefore, future studies of efficacy and safety dosage of C. xanthorrhiza extract and its active compounds in targeted therapeutic areas are compulsory. However, it is not recommended to use C. xanthorrhiza or preparations thereof during breastfeeding since curcumin and/or active compounds are transferred to sucklings via lactation.

\section{Conclusion and Perspective}

The present review summarizes comprehensive information about botany and distribution, traditional medication uses, production and conservation status, phytochemical attributes, and pharmacological properties of C. xanthorrhiza Roxb. The preliminary pharmacodynamic data shows that C. xanthorrhiza may strengthen bile secretion sometimes following oral administration [53, 101]. The main active components to trigger this action have been shown to be curcumin and camphor $[53,101]$. This could be related to the traditional application of $C$. xanthorrhiza in digestive disorder due to bile secretion deficiency, such as flatulence, slow digestion, and feelings of fullness. However, the quantity of metabolite required to produce this effect seems to be much greater than the traditional dose. Hence, the reference to the effect on bile secretion should be omitted from the indication. Based on this consideration, there is no need for contraindication for biliary obstruction. However, caution is taken in case of biliary obstruction. Nevertheless, more comprehensive pharmacokinetic and pharmacodynamics evaluation should be conducted before clinical test.

Furthermore, some issues regarding this C. xanthorrhiza still remain unclarified. Firstly, C. xanthorrhiza is commonly combined with other jamu plants (such as Zingiber officinale and Curcuma longa) in traditional therapies. The synergetic effects and underlying mechanisms between C. xanthorrhiza and other jamu plants should be studied in detail. Secondly, though rhizome is traditionally used as jamu ingredient, some scientists investigated the active component of other parts (such as flower bract) and demonstrated their pharmacological activities. Therefore, it is essential to compare the secondary metabolites and corresponding biological activities among various organs of this plant. Thirdly, reported pharmacological studies mostly focused on a limited number of metabolites (mainly xanthorrhizol and curcumin). Therefore, we need to answer if these explored chemicals can achieve the equivalent effect of C. xanthorrhiza, or, if not, to what extent. Otherwise, more phytochemicals should be elucidated using bioactivity-guided isolation methods. Fourthly, the molecular mechanisms underlying the biological activities of terpenoids and curcuminoids of C. xanthorrhiza remain inadequate. Thus, we believe that further investigations should focus on the absorption, metabolism, distribution, and excretion pathways of those main major groups of chemicals within C. xanthorrhiza. We believe that if the above questions are successfully answered in depth and identify more medical potential of C. xanthorrhiza, we can take more benefit from it for the sake of human health.

In conclusion, though many reports already exist on the local uses, isolated active compounds, and pharmacological activities of C. xanthorrhiza, some important research space still needs to be addressed such as comprehensive toxicity tests, optimized biotechnological production, and extensive clinical study to support its sustainable commercial application. Nevertheless, this review could be used as a basis for further research and commercialization of this plant and lead to the validation of unconfirmed ethnomedicinal claims.

\section{Conflicts of Interest}

The authors declare no conflicts of interest.

\section{Authors' Contributions}

ER collected and analyzed all main data and wrote the manuscript. JL provided data on chemical structures. YMK helped in intellectual advisement and substantial revision of the manuscript. All the authors read and approved the final manuscript. 


\section{Acknowledgments}

This project was supported by the Development of Sustainable Application for Standard Herbal Resources (KSN2012320), Korea Institute of Oriental Medicine through the Ministry of Science and ICT, Republic of Korea.

\section{References}

[1] L. S. de Padua, N. Bunyapraphatsara, and R. H. M. J. Lemmens, "Plants resources of south east asia," Medicinal and Pousionous Plants 1, Backhuys Publishers, vol. 12, p. 711, Leiden, Netherlands, 1999.

[2] N. A. Salleh, S. Ismail, and M. R. Ab Halim, "Effects of Curcuma xanthorrhiza extracts and their constituents on phase II drug-metabolizing enzymes activity," Pharmacognosy Research, vol. 8, no. 4, pp. 309-315, 2016.

[3] BPS-Statistics Indonesia, Statistics of Medicinal Plants Indonesia, BPS-statistics Indonesia, Jakarta, Indonesia, 2019.

[4] D. Haan, Therapie Compendium, Vierde Druk, D.,B.Centen's Uitgevers-Maatschappij N.V., Amsterdam, Netherlands, 1949.

[5] K. Heyne, Tumbuhan Berguna Indonesia: Jilid I, Translated by Badan Litbang Kehutanan, Koperasi Karyawan Departemen Kehutanan, Jakarta Pusat, 1987.

[6] R. Adila, Nurmiati, and A. Agustien, "Uji antimikroba curcuma spp. terhadap pertumbuhan Candida albicans, Staphylococcus aureus, dan Escherichia coli," Journal Biologi University of Andalas, vol. 2, no. 1, pp. 1-7, 2013.

[7] K. A. Susila, A. T. Tellu, and L. Tangge, "Jenis dan pemanfaatan tanaman obat di Desa Tinading dan pengembangannya sebagai media pembelajaran," Journal Ilmiah Pendidikan Biologi, vol. 5, no. 2, pp. 60-70, 2017.

[8] E. Sudarsi, Serat Primbon Djampi-Djampi Djawi, Wissenschaftsverlag, Mannheim, Germany, 1993.

[9] R. Salea, E. Widjojokusumo, B. Veriansyah, and R. R. Tjandrawinata, "Optimizing oil and xanthorrhizol extraction from Curcuma xanthorrhiza Roxb. rhizome by supercritical carbon dioxide," Journal of Food Science and Technology, vol. 51, no. 9, pp. 2197-2203, 2014.

[10] Y. Ozaki, "Antiinflammatory effect of Curcuma xanthorrhiza Roxb. and its active principles," Chemical and Pharmaceutical Bulletin, vol. 38, no. 4, pp. 1045-1048, 1990.

[11] J. K. Hwang, J. S. Shim, and Y. R. Pyun, "Antibacterial activity of xanthorrhizol from Curcuma xanthorrhiza against oral pathogens," Fitoterapia, vol. 71, no. 200, pp. 321-323, 2000.

[12] S.-C. Lin, C.-W. Teng, C.-C. Lin, Y.-H. Lin, and S. Supriyatna, "Protective and therapeutic effect of the Indonesian medicinal HerbCurcuma xanthorrhizaon $\beta$-DGalactosamine-induced liver damage," Phytotherapy Research, vol. 10, no. 2, pp. 131-135, 1996.

[13] T. Masuda, J. Isobe, A. Jitoe, and N. Nakatani, "Antioxidative curcuminoids from rhizomes of Curcuma xanthorrhiza," Phytochemistry, vol. 31, no. 10, pp. 3645-3647, 1992.

[14] C. S. Lim, D.-Q. Jin, H. Mok et al., "Antioxidant and antiinflammatory activities of xanthorrhizol in hippocampal neurons and primary cultured microglia," Journal of Neuroscience Research, vol. 82, no. 6, pp. 831-838, 2005.

[15] S. H. Kim, K. O. Hong, J. K. Hwang, and K.-K. Park, "Xanthorrhizol has a potential to attenuate the high dose cisplatin-induced nephrotoxicity in mice," Food and Chemical Toxicology, vol. 43, no. 1, pp. 117-122, 2005.
[16] J. H. Park, K. K. Park, M. J. Kim, J. K. Hwang, S. K. Park, and W. Y. Chung, "Cancer chemoprotective effects of Curcuma xanthorrhiza," Phytotherapy Research, vol. 22, no. 5, pp. 695-698, 2008.

[17] S. Ruslay, F. Abas, K. Shaari et al., "Characterization of the components present in the active fractions of health gingers (Curcuma xanthorrhiza and Zingiber zerumbet) by HPLCDAD-ESIMS," Food Chemistry, vol. 104, no. 3, pp. 1183-1191, 2007.

[18] S. Yasni, K. Imaizumi, K. Sin, M. Sugano, G. Nonaka, and Sidik, "Identification of an active principle in essential oils and hexane-soluble fractions of Curcuma xanthorrhiza Roxb. Showing triglyceride-lowering action in rats," Food and Chemical Toxicology, vol. 32, no. 3, pp. 273-278, 1994.

[19] S.-I. Uehara, I. Yasuda, K. Takeya, and H. Itokawa, "Terpenoids and curcuminoids of the rhizoma of Curcuma xanthorrhiza ROXB," Yakugaku Zasshi, vol. 112, no. 11, pp. 817-823, 1992.

[20] M. A. Sukari, N. Y. Rashid, S. W. Tang et al., "Chemical constituents and bioactivity of Curcuma xanthorrhiza Roxb." Journal of Ultra Scientist of Physical Science, vol. 20, pp. 605-610, 2008.

[21] C.-M. Zhang, P.-H. Fan, M. Li, and H.-X. Lou, "Two new sesquiterpenoids from the rhizomes ofCurcuma xanthorrhiza," Helvetica Chimica Acta, vol. 97, no. 9, pp. 1295-1300, 2014.

[22] Y. Cheah, F. Nordin, R. Sarip et al., "Combined xanthorrhizol-curcumin exhibits synergistic growth inhibitory activity via apoptosis induction in human breast cancer cells MDA-MB-231," Cancer Cell International, vol. 9, no. 1, pp. 1-12, 2009.

[23] E. S. Aziz and A. Dana, "Elisitasi kultur sel temulawak (Curcuma xanthorrhiza Roxb) untuk produksi senyawa aktif xantorizol," Acta Pharmaceutica Indonesia, vol. 39, no. 1, pp. 15-17, 2014.

[24] G. Parastaka and E. Nihayati, "Respon pertumbuhan planlet tanaman Temulawak (Curcuma xanthorrhiza Roxb.) klon Jember dan Pasuruan terhadap berbagai konsentrasi kolkisin," Jurnal Produksi Tanaman, vol. 7, no. 2, pp. 261-267, 2019.

[25] R. Rukmana, Temulawak: Tanaman Rempah Dan Obat, Kanisius, Yogyakarta, Indonesia, 1995.

[26] S. Dalimartha, Atlas Tumbuhan Obat Indonesia, Trubus Agriwidya, Jakarta, Indonesia, 2000.

[27] A. N. S. Thomas, Tanaman Obat Tradisional, Penerbit Kanisius, " Yogyakarta, Indonesia, 1989.

[28] P. O. Staub, M. S. Geck, Hardinsyah, C. S. Weckerle, L. Casu, and M. Leonti, "Classifying diseases and remedies in ethnomedicine and ethnopharmacology," Journal of Ethnopharmacology, vol. 174, pp. 514-519, 2015.

[29] M. Dewi, M. Aries, Hardinsyah, C. M. Dwiriani, and N. Januwati, "Knowledge on health benefit of Curcuma xanthorrhiza and the clinical trial of its effect on humoral immune system in obese adults," Indonesian Journal of Agriculture Science, vol. 17, no. 3, pp. 166-171, 2012.

[30] M. E. Kuntorini, "Economic botany of Zingiberaceae as traditional medicine by the community in Banjarbaru City," Bioscientiae, vol. 2, no. 1, pp. 25-36, 2005.

[31] M. F. Royyani, V. B. Lestari, A. Agusta, and O. Efendy, "Kajian etnobotani ramuan pasca melahirkan pada masyarakat enggano," Berita Biologi, vol. 17, no. 1, pp. 31-38, 2018.

[32] I. Dianto, S. Anam, and A. Khumaidi, "Studi etnofarmasi tumbuhan berkhasiat obat pada suku kaili ledo di kabupaten sigi, provinsi Sulawesi tengah," Jurnal Farmasi Galenika 
(Galenika Journal of Pharmacy) (E-Journal), vol. 1, no. 2, pp. 85-91, 2015.

[33] N. Sari, B. F. Wahidah, and N. Gaffar, "Etnobotani tumbuhan yang digunakan dalam pengobatan tradisional di kecamatan Sinjai Selatan Kabupaten Sinjai Sulawesi Selatan," Prosiding Seminar Nasional Biology for Life, vol. 3, no. 1, 2017.

[34] M. N. Irsyad and J. Murningsih, "Ethnobotany study of community in sukolilo village, kendeng pati, central Java," Bioma, vol. 15, no. 1, pp. 27-34, 2013.

[35] G. P. Fitria, A. Retnoningsih, and A. Irsadi, "Plant ethnobotani in keseneng village, sumowono district, semarang regency, central Java," Unnes Journal of Life Science, vol. 1, no. 2, pp. 252-277, 2012.

[36] T. Anggraini and T. U. Murningsih, "Note on royal titles in the surakarta palaces," Javanese Literature in Surakarta Manuscripts, vol. 7, no. 3, pp. 13-14, 2018.

[37] M. Q. Izzuddin and R. Azrianingsih, "Inventory of medicinal plants in kampung adat urug, urug village, sukajaya district, bogor regency," Natural B, vol. 3, no. 1, pp. 81-92, 2015.

[38] R. Mariani, A. Qowiyyah, and I. Fitriyanti, "Study of ethnopharmacognosy-ethnopharmacology of plants as medicine in kampung naga, salawu district, tasikmalaya regency," Jurnal Farmasi Galenika, vol. 2, no. 1, pp. 30-35, 2015.

[39] R. A. M. R. Syamsudin, F. Perdana, F. S. Mutiaz et al., "Temulawak plant (Curcuma xanthorrhiza Roxb.) as traditional medicine," Farmako Bahari, vol. 10, pp. 51-65, 2019.

[40] Y. Rukayadi and J.-K. Hwang, "In vitro activity of xanthorrhizol against Streptococcus mutans biofilms," Letters in Applied Microbiology, vol. 42, no. 4, pp. 400-404, 2006.

[41] W. Mangunwardoyo, Deasywati, and T. Usia, "Antimicrobial and identification of active compound Curcuma xanthorrhiza Roxb." International Journal of Basic and Applied Science, vol. 12, no. 1, pp. 69-78, 2012.

[42] L. Y. Lee, J.-S. Shim, Y. Rukayadi, and J.-K. Hwang, "Antibacterial activity of xanthorrhizol isolated from Curcuma xanthorrhiza Roxb. against foodborne pathogens," Journal of Food Protection, vol. 71, no. 9, pp. 1926-1930, 2008.

[43] N. W. M. Warmasari, D. K. Ernawati, A. W. Indrayani, N. W. S. Dewi, and I. M. Jawi, "Antibacterial activity from temulawak extract (Curcuma xanthorrhiza Roxb) on growth inhibition of Staphylococcus epidermidis in vitro," Jurnal Epidemologi Kesehatan, vol. 5, no. 1, pp. 1-7, 2020.

[44] W. S. Sylvester, R. Son, K. F. Lew, and Y. Rukayadi, “Antibacterial activity of Java turmeric (Curcuma xanthorrhiza Roxb.) extract against Klebsiella pneumoniae isolated from several vegetables," International Food Reserach Journal, vol. 22, no. 5, pp. 1770-1776, 2015.

[45] D. Prijatmoko, N. L. Syafira, and P. E. Lestari, “Antibacterial activity of essential oil extracts from Curcuma xanthorrhiza Roxb. rhizomes against bacteria causing pulp necrosis," Journal of Dentomaxillofacial Science, vol. 3, no. 3, pp. 144-148, 2018.

[46] S. Kumala, D. Rahmat, Y. Farida, and B. Chandra, "Antibacterial activity of ethanolic extract of Javanese turmeric rhizome entrappted in nanoparticles: a novel rule of chitosan," International Journal of Applied Pharmaceutics, vol. 10, no. 6, pp. 298-302, 2018.

[47] I. Batubara, I. Julita, L. K. Darusman, A. M. Muddathir, and T. Mitsunaga, "Flower bracts of temulawak (Curcuma xanthorrhiza) for skin care: anti-acne and whitening agents," Procedia Chemistry, vol. 14, pp. 216-224, 2015.

[48] Y. Rukayadi and J. K. Hwang, "In vitro activity of xanthorrhizol isolated from the rhizome of Javanese turmeric
(Curcuma xanthorrhiza roxb.) against Candida albicans biofilms," Phytotherapy Research, vol. 27, no. 7, pp. 1061-1066, 2013.

[49] Y. Rukayadi and J.-K. Hwang, "In vitro antimycotic activity of xanthorrhizol isolated from Curcuma xanthorrhiza Roxb. against opportunistic filamentous fungi," Phytotherapy Research, vol. 21, no. 5, pp. 434-438, 2007.

[50] H. Diastuti, A. Asnani, and M. Chasani, "Antifungal activity of curcuma xanthorrhiza and curcuma soloensis extracts and fractions," IOP Conference Series: Materials Science and Engineering, vol. 509, pp. 1-5, 2019.

[51] C. Pandji, C. Grimm, V. Wray, L. Witte, and P. Proksch, "Insecticidal constituents from four species of the zingiberaceae," Phytochemistry, vol. 34, no. 2, pp. 415-419, 1993.

[52] S. K. Lee, C. H. Hong, S. K. Huh et al., "Suppressive effect of natural sesquiterpenoids on inducible cyclooxygenase (COX-2) and nitric oxide synthase (iNOS) activity in mouse macrophage cells," Journal of Environmental Pathology, Toxicology, and Oncology, vol. 21, pp. 141-148, 2002.

[53] S. Yasni, K. Imaizumi, and M. Sugano, "Effects of an Indonesian medicinal plant, curcuma xanthorrhiza roxb., on the levels of serum glucose and triglyceride, fatty acid desaturation, and bile acid excretion in streptozotocin-induced diabetic rats," Agricultural and Biological Chemistry, vol. 55, no. 12, pp. 3005-3010, 1991.

[54] M.-B. Kim, C. Kim, Y. Song, and J.-K. Hwang, “Antihyperglycemic and anti-inflammatory effects of standardized Curcuma xanthorrhiza Roxb. extract and its active compound xanthorrhizol in high-fat diet-induced obese mice," Evidence-Based Complementary and Alternative Medicine, vol. 2014, Article ID 205915, 10 pages, 2014.

[55] S. Yasni, K. Imaizumi, M. Nakamura, J. Aimoto, and M. Sugano, "Effects of Curcuma xanthorrhiza Roxb. and curcuminoids on the level of serum and liver lipids, serum apolipoprotein A-I and lipogenic enzymes in rats," Food and Chemical Toxicology, vol. 31, no. 3, pp. 213-218, 1993.

[56] S. Hwan Kim, K. O. Hong, W. Y. Chung, J. K. Hwang, and K. K. Park, "Abrogation of cisplatin-induced hepatotoxicity in mice by xanthorrhizol is related to its effect on the regulation of gene transcription," Toxicology and Applied Pharmacology, vol. 196, no. 3, pp. 346-355, 2004.

[57] N. Manalu, B. B. Santoso, and M. L. Pulung, "Antimalarial activity by hem polymerization inhibition ekstract powder of temulawak (Curcuma xanthorrhiza roxb) from Manokwari, west Papua," Prosiding Seminar Nasional MIPA Unipa, vol. 3, no. 1, pp. 77-84, 2018.

[58] H. P. A. Mary, G. K. Susheela, S. Jayasree, A. M. Nizzy, B. Rajagopal, and S. Jeeva, "Phytochemical characterization and antimicrobial activity of Curcuma xanthorrhiza Roxb," Asian Pacific Journal of Tropical Biomedicine, vol. 2, no. 2, pp. 637-640, 2012.

[59] M. Lechtenberg, B. Quandt, and A. Nahrstedt, "Quantitative determination of curcuminoids in Curcuma rhizomes and rapid differentiation of Curcuma domestica val. and Curcuma xanthorrhiza Roxb. by capillary electrophoresis," Phytochemical Analysis, vol. 15, no. 3, pp. 152-158, 2004.

[60] T. Awin, A. Mediani, Maulidiani et al., "Phytochemical and bioactivity alterations of Curcuma species harvested at different growth stages by NMR-based metabolomics," Journal of Food Composition and Analysis, vol. 77, pp. 66-76, 2019.

[61] J.-H. Park, Y.-J. Jung, S. Shrestha et al., "Inhibition of NO production in LPS-stimulated RAW264.7 macrophage cells with curcuminoids and xanthorrhizol from the rhizome of Curcuma xanthorrhiza Roxb. and quantitative analysis using 
HPLC," Journal of the Korean Society for Applied Biological Chemistry, vol. 57, no. 3, pp. 407-412, 2014.

[62] S.-i. Uehara, I. Yasuda, K. Takeya, and H. Itokawa, "New bisabolane sesquiterpenoids from the rhizomes of Curcuma xanthorrhiza (Zingiberaceae)," Chemical and Pharmaceutical Bulletin, vol. 37, no. 1, pp. 237-240, 1989.

[63] C. Zhang, J. Ji, M. Ji, and P. Fan, "Acetylcholinesterase inhibitors and compounds promoting SIRT1 expression from Curcuma xanthorrhiza," Phytochemistry Letters, vol. 12, pp. 215-219, 2015.

[64] D. Friedrich and F. Bohlmann, "Total synthesis of various elemanolides," Tetrahedron, vol. 44, no. 5, pp. 1369-1392, 1988.

[65] E. Kozhevnikova, J. Quartararo, and I. V. Kozhevnikov, "Fries rearrangement of aryl esters catalysed by heteropoly acid," Applied Catalysis A: General, vol. 245, no. 1, pp. 69-78, 2003.

[66] Z. Wang, K.-J. Wang, C.-S. Cheng, N. Li, T.-M. Wang, and L. Dia, "Gingerol derivatives from the rhizomes of Zingiber officinale," Zeitschrift für Naturforschung B, vol. 66, no. 7, pp. 740-744, 2011.

[67] S. Samanhudi, A. Yunus, B. Pujiasmanto, and A. Saras, "In vitro propagation of temulawak (Curcuma xanthorrhiza Roxb.)," Jurnal Jamu Indonesia, vol. 2, no. 2, pp. 37-42, 2017.

[68] S. F. Syahid and E. Hadipoentyanti, Protokol Perbanyakan Benih Temulawak (Curcuma xanthorrhiza) Secara in Vitro, Balai Penelitian Tanaman Rempah dan Obat, Bogor, Indonesia, 2010.

[69] D. Maretta, D. Efendi, S. A. Aziz, and D. R. Sastra, "In vitro microrhizome formation of temulawak (Curcuma xanthorrhiza Roxb.)," in Proccedings of the 2nd International Symposium on Temulawak, pp. 11-15, Indonesia, December 2011.

[70] N. N. Kristina and S. F. Syahid, "The effect of coconut water on in vitro shoot multiplication, rhizome production, and the xanthorrizol content of ginger in the field," Industrial Crops Research Journal, vol. 18, no. 3, pp. 125-134, 2012.

[71] Y.-Z. Fang, S. Yang, and G. Wu, "Free radicals, antioxidants, and nutrition," Nutrition, vol. 18, no. 10, pp. 872-879, 2002.

[72] T. M. Florence, "The role of free radicals in disease," Australian and New Zealand Journal of Ophtalmology, vol. 23, no. 1, pp. 3-7, 2005.

[73] A. Jitoe, T. Masuda, I. G. P. Tengah, D. N. Suprapta, I. W. Gara, and N. Nakatani, "Antioxidant activity of tropical ginger extracts and analysis of the contained curcuminoids," Journal of Agricultural and Food Chemistry, vol. 40, no. 8, pp. 1337-1340, 1992.

[74] A. Rosidi, A. Khomsan, B. Setiawan, H. Riyadi, and D. Briawan, "Antioxidant potential of temulawak (Curcuma xanthorrhiza Roxb)," Pakistan Journal of Nutrition, vol. 15, no. 6, pp. 556-560, 2016.

[75] I. Widyastuti, H. Z. Luthfah, Y. I. Hartono, R. Islamadina, A. T. Can, and A. Rohman, "Antioxidant activity of temulawak (Curcuma xanthorrhiza Roxb.) and its classification with chemometrics," Indonesian Journal of Chemometrics and Pharmaceutical Analysis, vol. 1, no. 1, pp. 29-42, 2021.

[76] S. Devaraj, S. Ismail, S. Ramanathan, and M. F. Yam, "Investigation of antioxidant and hepatoprotective activity of standardized Curcuma xanthorrhiza rhizome in carbon tetrachloride-induced hepatic damaged rats," The Scientific World Journal, vol. 2014, Article ID 353128, 8 pages, 2014.

[77] N. Dosoky and W. Setzer, "Chemical composition and biological activities of essential oils of Curcuma species," Nutrients, vol. 10, no. 9, p. 1196, 2018.
[78] H. S. Budi and I. Pebriani, "The difference of temperature and storage time on the antioxidant activity of Curcuma ethanol extract (Curcuma xanthorrhiza) using the DPPH," Systematic Reviews in Pharmacy, vol. 11, no. 4, pp. 332-336, 2020.

[79] L. Rosiyani, The Evaluation of Metabolic Change on Curcuma with Different Planting Time (Undergraduate Thesis), IPB University, Bogor, Indonesia, 2010.

[80] A. Akinola, S. Ahmad, and M. Maziah, "Total anti-oxidant capacity, flavonoid, phenolic acid and polyphenol content in ten selected species of zingiberaceae rhizomes," African Journal of Traditional, Complementary and Alternative Medicines, vol. 11, no. 3, pp. 7-13, 2014.

[81] I. Jantan, F. C. Saputri, M. N. Qaisar, and F. Buang, "Correlation between chemical composition of Curcuma domestica and Curcuma xanthorrhiza and their antioxidant effect on human low-density lipoprotein oxidation," Evidence-Based Complementary and Alternative Medicine, vol. 2012, pp. 1-10, 2012.

[82] V. Hajhashemi, G. Vaseghi, M. Pourfarzam, and A. Abdollahi, "Are antioxidants helpful for disease prevention?" Research in Pharmaceutical Science, vol. 5, no. 1, pp. 1-8, 2010.

[83] L. C. Nascimento da Silva, C. M. Bezerra Filho, R. A. D. Paula et al., "In vitrocell-based assays for evaluation of antioxidant potential of plant-derived products," Free Radical Research, vol. 50, no. 8, pp. 801-812, 2016.

[84] N. Setiawan, K. Ernawati, and S. A. Sudharwo, "Evaluation of antimycobacterial activity of Curcuma xanthorrhiza ethanolic extract against Mycobacterium tuberculosis H37Rv in vitro," Veterinary World, vol. 11, no. 3, pp. 368-372, 2012.

[85] P. M. Davidson, "Parabens and phenolic compounds," in Antimicrobials in Foods, P. M. Davidson and A. L. Branen, Eds., pp. 263-306, Marcel Dekker, New York, NY, USA, 2nd edition, 1993.

[86] S. F. Oon, M. Nallappan, T. T. Tee et al., "Xanthorrhizol: a review of its pharmacological activities and anticancer properties," Cancer Cell International, vol. 1, no. 100, pp. 1-15, 2015.

[87] S.-Y. Teow, K. Liew, S. A. Ali, A. S.-B. Khoo, and S.-C. Peh, "Antibacterial action of curcumin against Staphylococcus aureus: a brief Review," Journal of Tropical Medicine, vol. 2016, Article ID 2853045, 10 pages, 2016.

[88] A. Kumar, S. Dhamgaye, I. K. Maurya, A. Singh, M. Sharma, and R. Prasad, "Curcumin targets cell wall integrity via calcineurin-mediated signaling in Candida albicans," Antimicrobial Agents and Chemotherapy, vol. 58, no. 1, pp. 167-175, 2014.

[89] A. N. Nurfina, M. S. Reksohadiprodjo, H. Timmerman, U. A. Jenie, D. Sugiyanto, and H. van der Goot, "Synthesis of some symmetrical curcumin derivatives and their antiinflammatory activity," European Journal of Medicinal Chemistry, vol. 32, no. 4, pp. 321-328, 1997.

[90] W. Y. Chung, J. H. Park, M. J. Kim et al., "Xanthorrhizol inhibits 12-O-tetradecanoylphorbol-13-acetate-induced acute inflammation and two-stage mouse skin carcinogenesis by blocking the expression of ornithine decarboxylase, cyclooxygenase- 2 and inducible nitric oxide synthase through mitogen-activated protein kinases and/or the nuclear factorB," Carcinogenesis, vol. 28, no. 6, pp. 1224-1231, 2007.

[91] S. Kim, K. E. Kook, C. Kim, and J.-K. Hwang, "Inhibitory effects of Curcuma xanthorrhiza supercritical extract and xanthorrhizol on LPS-induced inflammation in HGF-1 cells and RANKL-induced osteoclastogenesis in RAW264.7 cells," 
Journal of Microbiology and Biotechnology, vol. 28, no. 8, pp. 1270-1281, 2018.

[92] H. Itokawa, F. Hirayama, K. Funakoshi, and K. Takeya, "Studies on the antitumor bisabolane sesquiterpenoids isolated from Curcuma xanthorrhiza," Chemical and Pharmaceutical Bulletin, vol. 33, no. 8, pp. 3488-3492, 1985.

[93] M.-A. Choi, S. H. Kim, W.-Y. Chung, J.-K. Hwang, and K.-K. Park, "Xanthorrhizol, a natural sesquiterpenoid from Curcuma xanthorrhiza, has an anti-metastatic potential in experimental mouse lung metastasis model," Biochemical and Biophysical Research Communications, vol. 326, no. 1, pp. 210-217, 2004.

[94] N. Ismail, A. H. Pihie, and M. Nallapan, "Xanthorrhizol induces apoptosis via the up-regulation of bax and p53 in HeLa cells," Anticancer Research, vol. 25, pp. 2221-2227, 2005.

[95] T. Handayani, S. Sakinah, M. Nallappan, and A. H. Pihie, "Regulation of p53-, Bcl-2- and caspase-dependent signaling pathway in xanthorrhizol-induced apoptosis of HepG2 hepatoma cells," Anticancer Research, vol. 27, pp. 965-971, 2007.

[96] H.-I. Oh, J.-S. Shim, S.-H. Gwon, H.-J. Kwon, and J.-K. Hwang, "The effect of xanthorrhizol on the expression of matrix metalloproteinase-1 and type-I procollagen in ultraviolet-irradiated human skin fibroblasts," Phytotherapy Research, vol. 23, no. 9, pp. 1299-1302, 2009.

[97] S. C. Lin, C. C. Lin, Y. H. Lin, S. Supriyatna, and C. W. Teng, "Protective and therapeutic effects of Curcuma xanthorrhiza on hepatotoxin-induced liver damage," The American Journal of Chinese Medicine, vol. 23, no. 3, pp. 243-254, 1995.

[98] M. Yamazaki, Y. Maebayashi, N. Iwase, and T. Kaneko, "Studies on pharmacologically active principles from Indonesian crude drugs. I. Principle prolonging pentobarbitalinduced sleeping time from Curcuma xanthorrhiza Roxb," Chemical and Pharmaceutical Bulletin, vol. 36, no. 6, pp. 2070-2074, 1988.

[99] S. Listyawati, "Toxicity studies of the rhizome Curcuma xanthorrhiza Roxb. and Curcuma zedoaria Roscoe on hematological and male reproduction system of mice (Mus musculus L.)," Biofarmasi Journal of Natural Product Biochemistry, vol. 4, no. 1, pp. 10-13, 2006.

[100] C. Li, B. Liu, J. Chang et al., "A modern in vivo pharmacokinetic paradigm: combining snapshot, rapid and full PK approaches to optimize and expedite early drug discovery," Drug Discovery Today, vol. 18, no. 1-2, pp. 71-78, 2013.

[101] Y. Ozaki and O. B. Liang, "Cholagogic action of the essential oil obtained from curcuma xanthorrhiza Roxb," Shoyyakugaku Zassi, vol. 42, pp. 257-263, 1988. 